\title{
A2M wt Allele
}

National Cancer Institute

\section{Source}

National Cancer Institute. A2M wt Allele. NCI Thesaurus. Code C105923.

Human A2M wild-type allele is located in the vicinity of $12 \mathrm{p} 13.31$ and is approximately 49 $\mathrm{kb}$ in length. This allele, which encodes alpha-2-macroglobulin protein, plays a role in various processes as a protease inhibitor. Mutations in this gene are associated with alpha-2-macrog lobulin deficiency and susceptibility to Alzheimer disease. 